\title{
THE EFFECT OF GOOD CORPORATE GOVERNANCE AND FINANCIAL DISTRESS ON REAL EARNINGS MANAGEMENT
}

\author{
Santi Yopie ${ }^{1)}$, Erika $^{2)}$ \\ Accounting Department, Economic Faculty, Universitas Internasional Batam, Batam ${ }^{1,2)}$ \\ santiyopie.uib@yahoo.com ${ }^{l)}$,erikaatann@gmail.com ${ }^{21}$
}

\begin{abstract}
This research aims to analyze the effect of good corporate governance and financial distress on real earnings management. The sample in this study is a manufacturing company listed on Indonesia Stock Exchange for the 2016-2020 period. Data collection in this study was carried out using secondary data taken from the company's financial statement. The data were analyzed and tested using the SPSS 25 program to test descriptive statistics and outlier tests. The Smart PLS 3.0 program was used to test validity and reliability, test quality indexes, and test hypotheses. The results of this study indicate that institutional ownership has a significant effect on real earnings management, managerial ownership has no significant effect on real earnings management, family ownership has no significant effect on real earnings management, the audit committee has a significant effect on real earnings management, audit quality has a significant effect on management. Financial distress has a significant effect on real earnings management. The moderating variable in this study proves that family ownership has no significant effect on real earnings management which is moderated by political connections.
\end{abstract}

Keywords: Real Earnings Management; Institutional Ownership; Managerial Ownership; Family Ownership; Audit Committee; Audit Quality; Financial Distress; Political Connections.

*Corresponding author :

Email: santiyopie.uib@yahoo.com

DOI: https://doi.org/10.33369/j.akuntansi.11.3.285-306

\section{INTRODUCTION}

Earnings management is an act of manipulating financial statements that have often been heard by exaggerating profits or minimizing profits (Santoso, 2021). The case allegedly carried out earnings management by PT Tiga Pilar Sejahtera Food Tbk in 2017. In this case, it was found that there was manipulation of the recording of financial statements on receivables where the receivables were overstated by reaching IDR 1.4 trillion, inflation funds worth IDR 4 trillion, revenue inflation of IDR 662 billion, EBITDA inflation of IDR 329 billion and there is a flow of funds of IDR 1.78 trillion to management (Wareza, 2019). PT Tiga Pilar Sejahtera Food also noted six distributors as third parties who have the context of investor protection. If a problem occurs, the third party is responsible. At the same time, the six distributor companies are affiliates (Mahadi, 2021).

In the financial statements, information about company profits can be seen. Financial statements are the information needed by decision-makers (such as investors and creditors) to decide whether they can invest in the company. Managers in the company must take action so that the company's financial statements are presented perfectly (Ningsih, 2015). Therefore, the reported earnings information must be presented in a quality and related to cash flow. The attitude taken or taken by the company to generate good profits is earnings management.

Earnings management is an administration which in the process of making financial statements is needed by outside parties because it affect earnings reporting. Management can use methods by making or creating regulations that speed up or slow down expenses and revenues, so the company's profits are according to company desired (Dwiyanti \& Astriena, 2018). The occurrence of earnings management due to the managers in the company who use 
the strategy of accounting in recording profits plunged the financial statements, resulting in financial information conforming to the actual circumstances.

Earnings management is always judged negatively because it presents financial information that is not in the right condition. This situation is due to the relationship of management with shareholders as well as interested parties collide or collide with each other. The management side expects a relatively high bonus by increasing or increasing the company's profits, while shareholders try to lower its profits to attract their shares back (Ningsih, 2015). Earnings management is divided into two approaches, namely real earnings management and accrual earnings management (Yulaeli, 2018). Research by Ningsih, (2015) results that managers prefer to do real earnings management than accrual earnings management. It is proven that is more difficult for auditors to find. Companies operated by family ownership structures or family business groups more likely to carry out earnings management actions. This situation causes a decrease in the quality of company earnings or an increase in the quality of company earnings by non-controlling and controlling shareholders.

Good corporate governance arises because the relationship between agents and principals is not good. This unfavourable relationship is triggered by reasons that information is not strong enough, leading to information asymmetry that may be affected by earnings management (Hidayanti \& Paramita, 2014). The principle of good corporate governance is a new pattern that can motivate the provision of bonus compensation to encourage management to manipulate the accounting numbers contained in the financial statements. To minimize conflicts with the parties concerned, financial reports prepared with accounting numbers are needed. The method used to control agency costs is through good corporate governance. Corporate governance is a rule that can regulate or coordinate the relationship between management, shareholders, government, creditors, employees and other external and internal stakeholders relating to the rights and obligations to control the company. There are four main factors to increase shareholder welfare and professionalism without leaving the interests of shareholdersresponsibility, transparency, fairness, and accountability (Susanto \& Pradipta, 2016).

Institutional ownership has the resources, capabilities, or opportunities to monitor, influence, and control managers' decisions in the company. Similarly, the literature shows that managers of highly concentrated firms have the opportunity to be closely monitored (Yulaeli, 2018). If most company ownership is in the hands of a few people, then the company is highly concentrated. The fewer people who own many shares, the more reasons they should focus on investing and thus monitoring the management of company affairs (Farouk \& Bashir, 2017). Institutional ownership is the structure of the shareholders owned by the institution. Institutional ownership has an important task in a company (Setiawati \& Lieany, 2016). This role can control the management consisting of shareholders and managers. Institutional ownership can minimize disputes between shareholders and managers. The presentation of share ownership by the institution will impact the process of preparing the company's financial statements, which is impossible in the absence of earnings management. Institutional ownership usually plays a role in monitoring a company that ensures an increase in shareholder wealth due to a large investment in the company. Setiawati \& Lieany (2016) shows research on the significant negative effect of institutional ownership on real earnings management. This situation shows that institutional ownership is the largest shareholder who can monitor the company's operations and limit managers to profit from themselves, so managers are not relaxed in manipulating real profits generated by the company. This research are in line with Susanto \& Pradipta (2016) research. Then it can be formulated into the following hypothesis:

\section{$H_{1}$ : Institutional ownership has a significant negative impact on real earnings management.}


Shareholders can pressure managers to increase company profits, thereby achieving market value and because of this pressure, manager carry out earnings management. Managerial ownership can equalize the interests of managers and company investors because the manager is the manager and owner of the company. Managerial ownership is the ownership structure owned by company managers. There are many owners of the company's shares, one of which is owned by the manager. The company manager confirmed this action. This arrangement is because the manager's ownership determines policies and decisions related to forming financial statements following applicable standards (Hidayanti \& Paramita, 2014). When a company has managerial ownership, it reflects the distribution of company power between managers and shareholders. Hidayanti \& Paramita (2014) shows research on the significant positive impact of managerial ownership on real earnings management. It shows a higher managerial ownership structure will not change management's opportunistic attitude and behaviour on its real earnings management. This research are in line with Kamardin (2014) research. Then it can be formulated into the following hypothesis:

\section{$H_{2}$ : Managerial ownership has a significant positive impact on real earnings management.}

Family ownership in companies can affect the quality of financial reports because families usually occupy or hold important positions in the company which causes family companies to be compelled to report higher profits than non-family companies. The increasing concentration of family ownership, the higher the earnings management actions taken. Companies with family members have their own characteristics, namely the involvement of members and the role of families in running or managing the company. The ownership structure is very important because of the problems caused by the company's breakdown of ownership and management. The important factor is family. The family is the controlling shareholder which causes the alignment of the interests of all family shareholders to lead to long-term management and is more concerned with the company's image. Therefore, the family is an important factor in quality earnings information. Yulaeli (2018) and Ghaleb, Kamardin, \& Tabash (2020) show research on family ownership's significant negative effect on real earnings management. Because family is the controlling shareholder, the owner of the company can easily supervise the manager better. With the presence of family shareholders can focus more on long-term investment than other shareholders. Company owners also tend to focus on the company's reputation to build good relationships with third parties. Then it can be formulated into the following hypothesis:

\section{$H_{3}$ : Family ownership has a significant negative impact on real earnings management.}

The audit committee is an important person in a company. The committee is called the eyes and ears of the board of commissioners in monitoring industry operations. The creation of effective monitoring in the company intersects with the amount of resources owned by the audit committee (Wicaksono, Pambudi, \& Miftah (2016). Effective monitoring can prevent or reduce management from giving bad grades of financial reports. The characteristics of a good audit committee can affect the efficiency of the audit committee in carrying out its duties. For management to be more careful in carrying out company activities, real earnings management actions can be avoided in preparing company financial statements (Kharashgah, Amran, \& Ishak, 2019). Haji-Abdullah \& Wan-Hussin (2015) audit committee is measured by the size of the audit committee, audit committee meetings, audit committee independence and audit committee expertise have a significant negative impact on real earnings management. This research are in line with research by Wicaksono et al., (2016) which resulted in significant 
THE EFFECT OF GOOD CORPORATE GOVERNANCE AND FINANCIAL DISTRESS ON REAL EARNINGS MANAGEMENT

Santi Yopie and Erika

negative ties on real earnings management. Then it can be formulated into the following hypothesis:

\section{$H_{4}$ : Audit committee has a significant negative impact on real earnings management}

The quality of financial statements is also an important factor in a company in terms of presentation, delivery, and so on to attract or trust investors. With this goal, the company will carry out earnings management. The quality of the financial statements will attract investors to invest in the company if it is good. One of them is audit quality which shows the auditor's ability to manage the company's financial information. The auditor's ability is always seen because it can weaken the quality of the company's financial statements. Boedhi \& Ratnaningsih (2017) research shows a significant positive on real earnings management. This situation proves that good quality auditors will encourage companies to bring out real earnings management. This research aligns with Lestari \& Aeni (2019) which shows a significant positive effect on real earnings management. Then it can be formulated into the following hypothesis:

\section{H5: Audit quality has a significant positive impact on real earnings management}

In the financial statements can be seen how the condition of the financial statements. Companies that are in financial distress will also carry out earnings management. Financial distress is not a new thing to hear, especially in a company. Companies experiencing financial distress are natural but not on an ongoing basis. There are times when finances are stable. Financial distress shows that the company is experiencing financial distress gradually and leads to bankruptcy (Muljono \& Suk, 2018). Companies that are in financial distress will carry out profit management both from excessive product production, reducing expenses from sales, general and administrative expenses that can increase or decrease profitability. Muljono \& Suk (2018), Yulaeli (2018), and Feldo, Rinaningsih, \& Yuliati (2019) research shows a significant negative impact between financial distress and real earnings management. Companies with negative earnings are prefer to carry out earnings management, namely by lowering profits and then being recognized as current expenses so that in the next period an increase in company profits can be seen, so that investors who view the financial statements will assume that the company has recovered from financial distress.

\section{$H_{6:}$ Financial distress has a significant negative impact on real earnings management}

Everyone must have good relations with friends, family, relatives and so on. The political relationship is a relationship related to the state. Political relationships tend to influence the influence of family ownership on earnings management (Ghaleb et al., 2020). Family plays an important role in a family because the family holds an important position in a company. Political relationships can have good and bad results as well as a person's reputation. The more famous the better because of the many connections to people. Research by Braam, Nandy, Weitzel, \& Lodh (2015) and Apriyani et al., (2019) research shows a significant positive impact on real earnings management. It proves that politically connected companies can replace accrual to real earnings management due to public monitoring, which causes detection risk to increase so that politically connected companies prefer to carry out real earnings management because it is less detectable. Then it can be formulated into the following hypothesis:

H7: Family ownership has a significant positive impact on real earnings management, moderated by political connections. 
From the description above, it can be described as a framework of thought as follows:

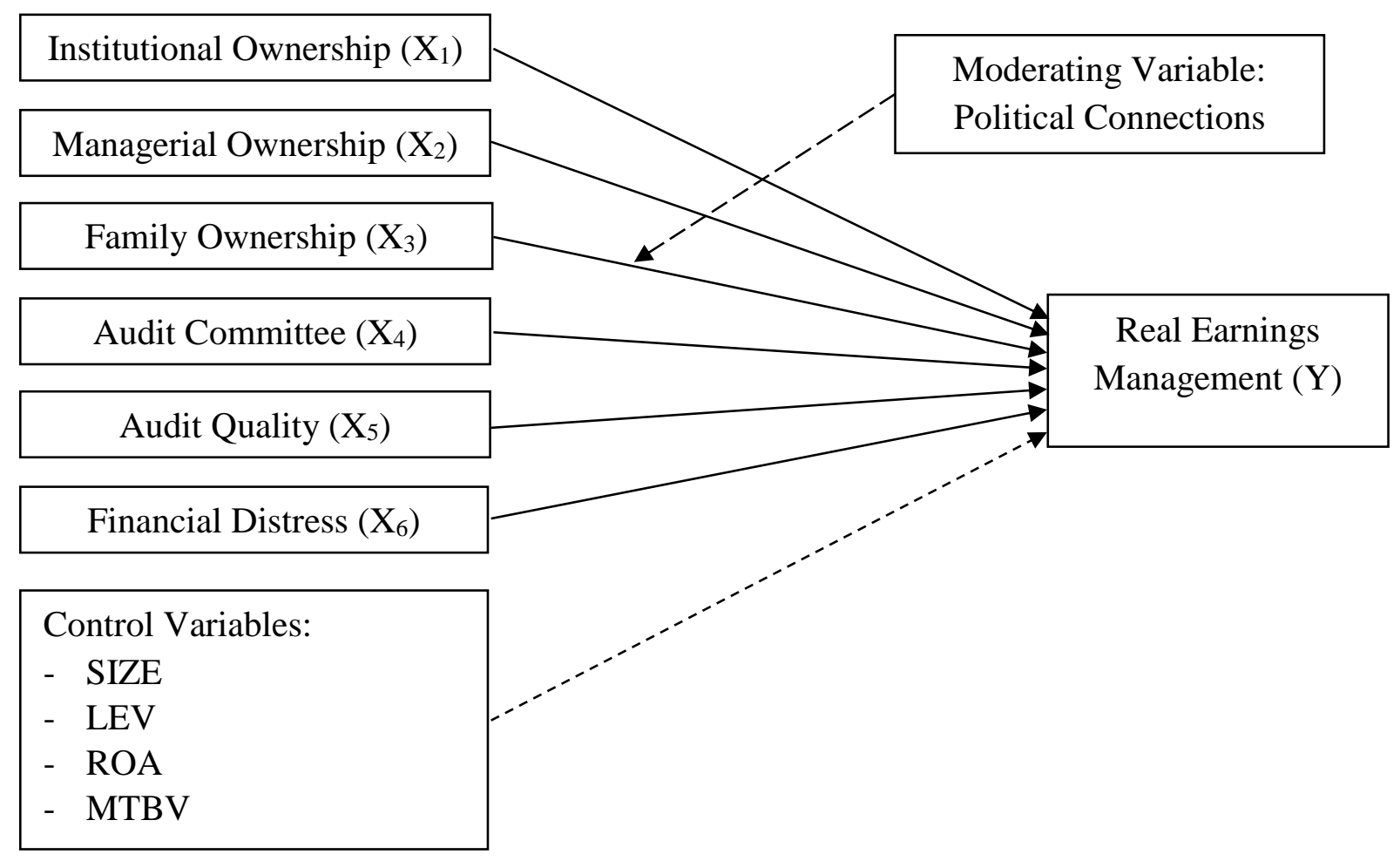

Figure 1. Research Conceptual Framework

\section{RESEARCH METHODS}

This research method used is the use of quantitative data. The subject of quantitative research is the use of one or more types of data whose purpose is to develop pre-existing research. The use of a descriptive approach because later it will produce descriptive data which basically uses a deductive-inductive approach. Quantitative methods are designed to test hypotheses, establish facts, prove relationships between variables, pass on descriptive statistics, and estimate results. Research models that use quantitative methods tend to be standardized, formal, structured and designed in such a way beforehand. This study also uses data with the type of collection time series, because the data used for research is over one period from 2016 to 2020. Assessment in terms of the characteristics of the problem, this study is included in a causal comparative study (Causal-Comparative) where the characteristic type is to find a causeand-effect relationship between variables where the assessment is done by comparing the variables. While historical research because the data collected and used on the object of this research is data, time series which means that it has happened in the past. The population are manufacturing companies that listed on the Indonesia Stock Exchange in 2016-2020. The secondary data from the company's financial and annual reports on IDX or the company's official website. The procedure for collecting data is literature study and documentation. Literature and documentation studies are used to obtain quantitative data from the financial statements. The research sample must have the following provisions:

1. Manufacturing company listed on the Indonesia Stock Exchange.

2. Manufacturing company that IPO before 2016.

3. Manufacturing company that have complete financial statements.

Analyzing data is the act of searching for information that can be useful to many people. The method in analyzing the data is needed to fulfill the question statement or to evaluate the 
assumptions that have been put forward. PLS is an equation model derived from Structural Equation Modeling (SEM) with a variance or component-based SEM approach. The data analysis method in this research is used Partial Least Square (PLS).

In the PLS method, the data is distributed free of charge without certain assumptions (categorical, interval, ratio, nominal and ordinal). PLS also uses random multiplication or bootstrap, where the assumption of normality is not an obstacle for PLS. In addition, PLS not required the use of minimum sample size in research, including even smaller sample sizes, can still use PLS. SEM is a useful technique to cover the weakness of the regression technique. SEM is divided into two methods: Covariance Based SEM (CBSEM) and methods Variance Based SEM or PLS. PLS is a powerful study review technique because it is not based on many assumptions. PLS is classified as a non-parametric type because it does not require a normal distribution of the PLS modeling data.

The weight estimate is used as a form of the latent variable score element obtained based on the outer model (measurement model as the relationship between the indicator and its construct) and the inner model (structural model as a link to latent variables) is determined. The target of using PLS is to make assumptions. In making these assumptions, it is by estimating the correlation between variables, Sso that the value of the latent variable is obtained which will help researchers in making predictions. The result is the residual variance of the dependent variable which has been minimized. The latent variable is linear from the number of parameters.

The evaluation of the limitations obtained using PLS is divided into the following types of categories: The first category is weight estimates which are useful for making estimates of latent variable scores. The second category is path estimation, which is a path estimate that reflects the variables connected to the latent variable with between latent variables and their indicator blocks (loading).

\section{Operational Definition and Variable Measurement}

Institutional Ownership

Institutional ownership is shares owned or purchased by institutions. The institution in question can be local or foreign. These institutions consist of mutual fund companies, insurance companies, pension funds, and other institutions in the form of companies. Institutional ownership in this study uses the ratio of issued shares and is ownership by institutions divided by total outstanding shares (Setiawati \& Lieany, 2016).

\section{Managerial Ownership}

Managerial ownership can influence the nature of decisions and thus affect the development of the company. Managers favour their personalities such as salary increases or status, because managers are generally consumptive and productive. Managerial ownership in this study uses the ratio of issued shares and is the ownership by managerial members divided by total outstanding shares (Hidayanti \& Paramita, 2014).

\section{Family Ownership}

An important factor in a company is the family because the family usually holds important positions or positions. Family ownership in this study uses the ratio of issued shares and is owned by family members divided by total outstanding shares (Ghaleb et al., 2020).

\section{Audit Committee}

\section{Audit Committee Size}

The size of the audit committee uses the number of audit committee members (Kharashgah et al., 2019). 
2. Independence of the Audit Committee

The independence of the audit committee is determined by Bapepam LK (2012), as follows:

a. People who are not in a legal consulting firm, public accounting firm, party providing insurance services or public appraisal service office, appraisal services, non-insurance services and other consulting services to issuers or related public companies in the last 6 months,

b. Except for independent commissioners, KA members are not persons who have worked or have the right to control, plan, supervise or lead the activities of issuers or public companies within the last 6 months.

c. Does not own shares indirectly or directly in issuers or public companies.

d. Has no affiliation with members of the directors, major shareholders or board of commissioners of the issuer or public company.

e. Does not have a good business relationship indirectly or directly related to the business activities of the public company or issuer.

3. Expertise of the Audit Committee

Following the provisions of the Minister of State regarding BUMN (No. Per12/MBU/2012 and Bapepam LK (2012)), the audit committee member is at least 1 person and must meet the following: requirements: accounting education background or expertise in finance. The two regulations do not describe the characteristics of audit committees with accounting education or financial expertise. According to the SEC definition in IAI (2015), financial experts have education and experience, including treasurer, head of accounting, public accountant, auditor or other experience with similar functions.

\section{Audit Committee Meetings}

Measurements of audit committee meetings use the number of meetings or meetings held within a period of 1 period (Kharashgah et al., 2019).

\section{Audit Quality}

The auditor must be able to detect material errors in financial statements. The quality of good financial statements describes a good auditor. Audit quality is an effort or ability of the auditor to catch material misstatements and report these errors simultaneously (Boedhi \& Ratnaningsih, 2017). Audit quality is measured using a dummy variable equal to ' 1 ' if a company employs Big 4 auditors and '0' otherwise. The Big 4 Audit Firms mentioned are as follows:
1. Deloitte Firm
2. PwC Firm
3. $\quad$ Ernest \& Young Firm
4. KPMG Firm

\section{Financial Distress}

Finance is an important factor in the company. With stable finances, the company will easily run the company, otherwise if the company's finances are unstable, it will be difficult to run the company's operations. Financial distress reflect the company's inability to pay off its obligations (Melinda \& Widyasari, 2019). The financial distress of this study was measured using the Altman model or the so-called Altman Z-Score formulated as follows:

Zscore $\left.=1,2\left(\frac{W C}{T A}\right)+1,4\left(\frac{R E}{T A}\right)+3,3\left(\frac{E B I T}{T A}\right)+0,6\left(\frac{M V E}{B V L}\right)+1,0\left(\frac{S A L E S}{T A}\right) \ldots \ldots \ldots . .1\right)$ 
THE EFFECT OF GOOD CORPORATE GOVERNANCE AND FINANCIAL DISTRESS ON REAL EARNINGS MANAGEMENT

Santi Yopie and Erika

Description:

$\mathrm{WC}=$ Working Capital

TA $=$ Total Assets

$\mathrm{RE} \quad=$ Retained Earnings

EBIT $=$ Earnings Before Interest and Tax

MVE = Market Value of Equity

$\mathrm{BVL}=$ Book Value of Liabilities

\section{Real Earnings Management}

REM is defined as an act of manipulation or management action that drifts away from business provisions to meet nominal income. It detects that there is a real manipulation of activities by examining cash flow from operations or cash flow operations (CFO), production costs (PRC) and discretionary costs (DIE), found consistent evidence that companies try to avoid losses by offering discounts for increasing sales, exaggerating manufacturing to minimize the cost of goods sold and reducing discretionary costs aggressively to lower margins (Ghaleb et al., 2020). Thus, to detect real earnings management, three methods are used, namely as follows:

\section{Sales Manipulation}

Ningsih (2015) sales manipulation is an action taken by a company to get temporarily increase sales by providing discounts, excessive goods and longer terms. Actions taken inadvertently will affect profits thereby increasing profits and cash flow (Khuong, Ha, \& Thu, 2019). Cash flow from operating activities is calculated as the residual or residual value of the calculation and is referred to as ACFO (abnormal cash flow from operations) with a small ACFO indicating high real earnings management. Sales manipulation is formulated as follows:

$$
\frac{\text { CFO }_{t}}{\text { Assets }_{t-1}}=\beta_{1}\left(\frac{1}{\text { Assets }_{t-1}}\right)+\beta_{2}\left(\frac{\text { sales }_{t}}{\text { Asset }_{t-1}}\right)+\beta_{3}\left(\frac{\Delta \text { Sales }_{t}}{\text { Assets }_{t-1}}\right)+\varepsilon_{t}
$$

Description:

$\mathrm{CFO}_{\mathrm{t}} \quad=$ Cash flow operations period $\mathrm{t}$.

Assets $_{\mathrm{t}-1}=$ total assets of the previous year.

Sales $\mathrm{t}_{\mathrm{t}} \quad=$ total sales in period $\mathrm{t}$.

$\Delta$ Sales $_{\mathrm{t}} \quad=$ change in total sales minus the previous year's sales.

\section{Overproduction}

Production is an activity that creates new products or adds quality to goods to meet needs (Adiguzel, 2013). Companies can produce or manufacture excess products because this action can lower the cost of goods sold. Production costs are calculated as the residual value of the calculation and are called APRC (abnormal production level). A large APRC indicates high real earnings management. This method can reduce COGS and increase profits (Ningsih, 2015) is formulated as follows:

$$
\frac{P^{2} C_{t}}{\text { Asset }_{t-1}}=\beta_{1}\left(\frac{1}{\text { Assets }_{t-1}}\right)+\beta_{2}\left(\frac{\text { sales }_{t}}{\text { Assets }_{t-1}}\right)+\beta_{3}\left(\frac{\Delta \text { Sales }_{t}}{\text { Asset }_{t-1}}\right)+\beta_{4}\left(\frac{\Delta \text { Sales }_{t-1}}{\text { Asset }_{t-1}}\right)+\varepsilon_{t}
$$

Description:

$\mathrm{PRC}_{\mathrm{t}}=$ sum of changes in inventory $(\Delta \mathrm{INV})$ and cost of goods sold $\left(\mathrm{COGS}_{\mathrm{t}}\right)$ at time $\mathrm{t}$.

Assets $_{\text {t } 1}=$ total assets of the previous year.

Sales $\mathrm{t}_{\mathrm{t}}=$ total sales in period $\mathrm{t}$. 
$\Delta$ Sales $_{\mathrm{t}} \quad=$ change in total sales minus the previous year's sales.

$\Delta$ Salest-1 $=$ change in sales related to sales of tofu in advance.

\section{Discretionary Cost Reduction}

Discretionary costs can be reduced or increased according to the company's decision (Farouk \& Bashir, 2017). The discretionary costs are the sum of general and administrative expenses, research and development expenses, advertising expenses, and selling expenses. Examples of discretionary costs are training costs, advertising costs, maintenance costs and so on. The company minimizes these reported costs to increase revenue. Discretionary costs are calculated as the residual or residual value of the calculation and are called ADIE (abnormal discretionary expenses) with a small ADIE indicating high earnings management. Discretionary costs are generally paid in cash, this reduces or decreases cash outflows and has a positive effect on operating cash flows formulated as follows:

$\left.\frac{\text { DIE }_{t}}{\text { Assets }_{t-1}}=\beta_{1}\left(\frac{1}{\text { Assets }_{t-1}}\right)+\beta_{2}\left(\frac{\text { sales }_{t-1}}{\text { Assets }_{t-1}}\right)+\varepsilon_{t} \ldots \ldots . .4\right)$

Description:

$\mathrm{DIE}_{\mathrm{t}} \quad=$ discretionary costs during period $\mathrm{t}$.

Assets $_{\mathrm{t}-1} \quad=$ total assets of the previous year.

Salest $1=$ total sales in the previous year.

Company Size is a size in the form of small or large in the company monitored from its assets. Firm size in this study uses the natural logarithm of total assets (Ghaleb et al., 2020). Leverage is used to measure company assets that are financed with long-term debt. Leverage estimates total debt divided by total assets (Ghaleb et al., 2020).

Return on Assets (ROA) in this study uses total net income divided by total assets. Companies that manipulate earnings tend to be motivated to improve company performance to make it look good (Ghaleb et al., 2020).

Market to Book Value of Equity (MTBV) in this study uses the market value of shares or market capitalization divided by the book value of shares or total equity for the period (Ghaleb et al., 2020).

\section{Political Connections}

The moderating variable of this research is political connection. Political relations can be used as the supporting indicators of a company. In this study, political connection is used as a moderating variable. Political connections can weaken or strengthen a company because of that reputation (Chandra, 2021). It is stated that there is a political connection if:

1. One director or board of commissioners arranges positions as a member of the state parliament/high state official (government cabinet), state institution official, and member of a political party.

2. There is one of the director or board of commissioners as a former high-ranking official or politician.

3. One of the owners/founders of the company or controlling shareholder is a government official / former government official and politician.

4. There is one of the director, commissioners, owners, or shareholders who have close relationships with politicians, political parties, government officials or former government 
THE EFFECT OF GOOD CORPORATE GOVERNANCE AND FINANCIAL DISTRESS ON REAL EARNINGS MANAGEMENT

Santi Yopie and Erika

officials. To limit subjectivity, close relationships in this study were determined according to family relationships and cases where close relatives or friends with politicians.

\section{RESULTS AND DISCUSSION}

The table presented below shows 192 companies listed on the IDX during the 2016-2020 period. During that period, there were also 49 companies whose IPOs after 2016, and there were eight companies whose financial statements were not available, there was 1 company whose company withdrew from the IDX. Thus the companies that realize the requirements to be researched are 134 companies with a total data sample of 670 data and there are 107 data outliers so that the data that can be studied reaches 563 data samples that can be studied. This study uses independent variables, namely institutional ownership, managerial ownership, family ownership, financial distress and audit committee. While the dependent factor is real earnings management. The control factors are leverage, return on assets, company size, and market to book value of equity.

Table 1. Sample Selection Criteria

\begin{tabular}{clc}
\hline No & \multicolumn{1}{c}{ Description } & Samples \\
\hline 1 & Manufacturing Company Listed on the IDX & 192 \\
\hline 2 & IPO After 2016 & $(49)$ \\
\hline 3 & Incomplete Financial Statements & $(8)$ \\
\hline 4 & Delisting from IDX & $(1)$ \\
\hline & $\quad$ Total & 134 \\
\hline
\end{tabular}

\section{Descriptive Statistics}

The table below displays descriptive statistics for regression such as dependent, independent, moderating, and control variables. The table presents the entire sample for descriptive statistics, including minimum, maximum, standard deviation and mean values.

Table 2. Descriptive Statistics

\begin{tabular}{lccccc}
\hline \multicolumn{1}{c}{ Variable } & $\mathrm{N}$ & Min & Max & Mean & $\begin{array}{c}\text { Standard } \\
\text { Deviation }\end{array}$ \\
\hline REM & 563 & -1.071 & 1.091 & 0.024 & 0.317 \\
\hline KI & 563 & 0.000 & 1.000 & 0.737 & 0.238 \\
\hline KM & 563 & 0.000 & 0.482 & 0.039 & 0.084 \\
\hline KF & 563 & 0.000 & 0.513 & 0.037 & 0.092 \\
\hline AC SIZE & 563 & 3.000 & 4.000 & 3.036 & 0.185 \\
\hline AC MEET & 563 & 0.000 & 22.000 & 5.801 & 3.360 \\
\hline AC IND & 563 & 2.000 & 4.000 & 3.021 & 0.222 \\
\hline AC EXPER & 563 & 0.000 & 4.000 & 2.075 & 0.794 \\
\hline KK & 563 & -7.388 & 27.680 & 3.313 & 3.863 \\
\hline SIZE (IDR 000.000) & 563 & 89.328 & 295.830 .000 & 9.901 .154 & 25.013 .202 \\
\hline LEV & 563 & 0.065 & 2.147 & 0.495 & 0.296 \\
\hline ROA & 563 & -0.401 & 0.921 & 0.037 & 0.101 \\
\hline MTBV & 563 & -8.540 & 20.594 & 1.555 & 2.004 \\
\hline
\end{tabular}


The minimum real earnings management (REM) figure of $-1,071$ is found at PT Akasha Wira International Tbk. The maximum number shows 1,091 found at PT. Alakasa Industrindo Tbk and the average value shows 0.024 with a standard deviation of $31.7 \%$ which means that the average company performs earnings management actions on real activities in the company. We have often heard of earnings management and many companies do it so that it is expected to be further raised to get bonuses.

For institutional ownership (KI) as measured by the percentage of share ownership of institutional companies from 563 samples that have a minimum score of 0.000 or $0 \%$, the maximum value of 1,000 or $100 \%$ is found at PT Lion Metal Works Tbk, the average number is 0.737 or $73.7 \%$ in the standard $23.8 \%$ deviation. This situation shows that there are companies whose share ownership is not owned by institutions called $0 \%$. The average number is greater than the standard deviation, which means that the change between the maximum and minimum figures during the observation period is small or there is no relatively small gap between the lowest and highest institutional ownership.

Managerial ownership (KM) shows a minimum number of 0.000 or $0 \%$, the maximum number shows 0.482 or $48.2 \%$ is found in PT Ultra Jaya Milk Industry \& Trading Company Tbk, which means that the management has a lot of shares so that managerial ownership is high. The mean value shows 0.039 or $3.9 \%$ with a standard deviation of $8.4 \%$. This shows that there are companies whose shares are not owned by managers and companies whose shares are owned by company managers.

Family ownership (KF) shows a minimum value of 0.000 or $0 \%$, the maximum number shows 0.513 or $51.3 \%$ taken by PT Intanwijaya Internasional Tbk for 2020 and the average value shows 0.037 or $3.7 \%$ with a standard deviation of $9.2 \%$. This situation indicates that there are companies whose shares are not owned by the family, namely $0 \%$ and there are companies whose share ownership is also owned by the family.

Audit Committee (AC) is measured by AC Size, AC Meetings, AC Independent, and AC Expertise. AC Size (AC S) displays a minimum number of 3, a maximum number of 4 , the average number shows 3,036 and a standard deviation of 0.185 . This situation shows that companies do not have audit committee members and have audit committee members. Generally from the sample, many trains consist of 3 people so that on the average value we can see it too. Based on the Financial Services Authority Regulation No. 55 / POJK.04 / 2015, the total number of people who must be on the audit committee in each company has been determined. In particular, the regulation stipulates that the number of audit committees must be a minimum of 3 (three) persons which an independent commissioner must chair. This situation shows that on average, all companies have KA of 3 people.

$\mathrm{AC}$ meeting $(\mathrm{AC} \mathrm{M})$ displays a minimum score of 0 , a maximum number of 22 , an average of 5,801 and a standard deviation of 3,360. This situation shows that companies hold meetings and some that do not hold meetings within a year. On average, companies that hold audit committee meetings are 5-6 times a year in the sample. Some companies do not disclose the number of audit committee meetings in the annual report. The Financial Services Authority Regulation No. 55 / POJK.04 / 2015 explains that the AC is expected to hold regular meetings at least once every three months. This is done to increase the effectiveness in carrying out the monitoring function.

$\mathrm{AC}$ independence (AC I) displays a minimum score of 2, a maximum score of 4 , an average number of 3,021, and a standard deviation of 0.222 . This situation proves that there are companies whose audit committee members are independent and some are not. On average in the company, because there are three audit committee members, it inadvertently affects the independence of the audit committee of 3 people. According to the regulations in Indonesia, the chairman of the audit committee is an independent commissioner and members of the 
company's audit committee are parties who are not affiliated with the company, which means that the audit committee is an independent member from outside the company.

AC expertise (AC E) shows a minimum score of 0 , a maximum score of 4 , an average value of 2,075 and a standard deviation of 0.794 . This situation proves that the expertise of KA members in the field of accounting and finance on average, each company has 2 people who have experience working in these fields. For the variable of financial distress (KK) shows a minimum value of $-7,388$ owned by PT Panasia Indo Resources Tbk. The maximum value indicates the value of 27,680 is found at PT Hanjaya Mandala Sampoerna Tbk. The average value shows 3,313 which proves that the sample in the study is included in the save zone with a standard deviation of 3,863 . This proves that there are companies experiencing distress and there are not distressed in terms of the save zone or gray area. From here it can be seen, the prediction of the bankruptcy of a company.

For the company size variable (SIZE), which uses the measurement of company assets presented in the table is millions of rupiah. The maximum amount is IDR 295,830,000,000,000 owned by PT Astra International Tbk, the minimum amount is IDR 89,327,328,853 owned by PT Primarindo Asia Infrastructure Tbk. The average number shows 9,901,154,936,807 with a standard deviation value of 25,013,202,406,256 indicating that the standard deviation of variation is low. Leverage (LEV) displays an average number of 0.495 which indicates the average amount of company assets financed by debt is $49.5 \%$. The lowest number from the test results is 0.065 which PT Inti Agri Resources own. The highest value from the test results, which is 2,147, is owned by PT Argo Pantes Tbk with a standard deviation of 0.296, which means that the standard deviation is highly variable. Return on assets (ROA) displays a minimum score of -0.401 owned by PT Keramika Indonesia Assosiasi Tbk. a maximum number of 0.921 owned by PT Merck Tbk. The average amount is 0.037 with a standard deviation is 0.101 . It shows that the percentage of profits obtained by the company with its assets.

Market to book value of equity (MTBV) showing a minimum number of $-8,540$ is found in PT Century Textile Tbk. The maximum value of 20,594 is found at PT Hanjaya Mandala Sampoerna Tbk. The average number is 1,555 with a standard deviation of 2,004. This situation proves that the company's growth prospects are stated in market price which are considered to be included in the stock price. The average number is lower than the standard deviation, which means that there is a high variation between the maximum and minimum numbers during the observation period.

Table 3. Statistic Descriptive Dummy Variable

\begin{tabular}{llll}
\hline \multicolumn{1}{c}{ Variable } & \multicolumn{1}{c}{ Category } & Total & Percent \\
\hline Audit Quality & $1:$ BIG 4 & 230 & $40.9 \%$ \\
\cline { 2 - 4 } & $0:$ NON BIG 4 & 333 & $59,1 \%$ \\
\hline Politic Connections & $1:$ Connection & 234 & $41.6 \%$ \\
\cline { 2 - 4 } & $0:$ No Connection & 329 & $58,1 \%$ \\
\hline
\end{tabular}

It can be seen that the audit quality variable (AQ) is categorized into 2 categories, namely KAP BIG 4 and NON-KAP BIG 4. It can be concluded that 230 data or as much as $40.9 \%$ of data use the services of KAP BIG 4. A total of 333 data or $59.1 \%$ of data do not use services of KAP BIG 4. This situation proves that KAP BIG 4 is less than NON KAP BIG 4.

Political connections (PC) are divided into two, namely, there are connections and there are no political connections. It can be concluded that there are 234 data whose members have political connections or $41.6 \%$ and as many as 329 data whose members have no connection or $58.4 \%$. This situation proves that the political connections in companies are greater than those without political connections. 


\section{Outer Model Evaluation}

Measurement model or external model shows how each parameter block is related to its latent variable. In the analyzed model, the correlation between latent variables and their parameters is determined by analysing the external model or measurement model. This process is carried out to find out that the indicators or research constructs have met the criteria of validity and reliability. The outer model is divided into 2 tests, namely validity and reliability.

\section{Convergent Validity}

Convergent validity is carried out to measure the accuracy of indicators in displaying latent variables. This test can be tested by looking at the Outer Loadings and Average Variance Extracted (AVE) values. If the correlation of individual reflection measurement with the construct to be measured by looking at the outer loading with a value $>0.60$ and the AVE has a value $>0.5$, it is considered to have met the criteria of convergent validity. According to Chin (taken by Imam Ghozali), an outer loading figure of around $0.50-0.60$ is acceptable.

Table 4. Loading Factor

\begin{tabular}{|c|c|c|c|c|c|c|c|c|c|c|c|c|}
\hline VAR & KI & KM & $\mathrm{KF}$ & $\mathrm{AC} \mathrm{S}$ & $\mathrm{AC} \mathrm{M}$ & AC I & $\mathrm{AC} E$ & $\mathrm{AQ}$ & KK & REM & KP & $\mathrm{KF} * \mathrm{KP}$ \\
\hline $\mathrm{KI}$ & 1.000 & & & & & & & & & & & \\
\hline KM & & 1.000 & & & & & & & & & & \\
\hline KF & & & 1.000 & & & & & & & & & \\
\hline AC S & & & & 0.819 & & & & & & & & \\
\hline $\mathrm{AC} \mathrm{M}$ & & & & & 0.674 & & & & & & & \\
\hline AC I & & & & & & 0.877 & & & & & & \\
\hline AC E & & & & & & & 0.129 & & & & & \\
\hline $\mathrm{AQ}$ & & & & & & & & 1.000 & & & & \\
\hline KK & & & & & & & & & 1.000 & & & \\
\hline REM & & & & & & & & & & 1.000 & & \\
\hline $\mathrm{KP}$ & & & & & & & & & & & 1.000 & \\
\hline $\mathrm{KF}^{*} \mathrm{KP}$ & & & & & & & & & & & & 0.944 \\
\hline
\end{tabular}

From the test results, each indicator has a high relationship with each construct because outer loadings explain the index's strength that affects each construct (latent variable) except audit committee expertise 0.129 is not enough.

From the test results to show the value of AVE on this model already meets the criteria of convergent validity because the value AVE on this study has been worth $>0.5$, except for the audit committee variable whose value is $<0.5$, which is 0.489 , so this variable does not meet the criteria. 
THE EFFECT OF GOOD CORPORATE GOVERNANCE AND FINANCIAL DISTRESS ON REAL EARNINGS MANAGEMENT

Santi Yopie and Erika

Table 5. Average Variance Extracted (AVE)

\begin{tabular}{cc}
\hline Variable & AVE \\
\hline KI & 1.000 \\
\hline KM & 1.000 \\
\hline KF & 1.000 \\
\hline AC & 0.489 \\
\hline AQ & 1.000 \\
\hline KK & 1.000 \\
\hline REM & 1.000 \\
\hline KP & 1.000 \\
\hline KF*KP & 1.000 \\
\hline SIZE & 1.000 \\
\hline LEV & 1.000 \\
\hline ROA & 1.000 \\
\hline MTBV & 1.000
\end{tabular}

\section{Discriminant Validity}

Discriminant validity relates to the principle that different indicators should not have high values. There are 3 criteria for this test where if it is fulfilled then the data has met the discriminant validity criteria. These criteria include cross loading which requires that the indicators must be united on each variable with a minimum value of 0.7 .

Table 6. Cross Loadings

\begin{tabular}{cccccccccccccc}
\hline & KI & KM & KF & AC & AQ & KK & REM & PC & KF*PC & SIZE & LEV & ROA & MTBV \\
\hline KI & 1.000 & -0.429 & -0.431 & -0.230 & 0.277 & 0.100 & -0.046 & -0.002 & 0.032 & 0.100 & -0.027 & 0.049 & 0.048 \\
\hline KM & -0.429 & 1.000 & 0.861 & -0.017 & -0.094 & -0.021 & -0.076 & -0.025 & 0.023 & -0.163 & -0.047 & 0.030 & 0.018 \\
\hline KF & -0.431 & 0.861 & 1.000 & -0.023 & -0.064 & 0.010 & -0.094 & -0.063 & -0.122 & -0.117 & -0.140 & 0.055 & 0.060 \\
\hline AC S & -0.177 & -0.017 & -0.014 & 0.900 & 0.075 & 0.022 & -0.082 & 0.208 & -0.047 & 0.213 & -0.032 & -0.002 & 0.085 \\
\hline AC M & -0.178 & 0.004 & -0.014 & 0.674 & 0.067 & -0.049 & -0.067 & 0.106 & 0.035 & 0.172 & 0.056 & 0.014 & -0.015 \\
\hline AC I & -0.191 & -0.001 & -0.001 & 0.821 & -0.015 & -0.053 & -0.042 & 0.179 & -0.032 & 0.099 & -0.030 & -0.053 & -0.029 \\
\hline AC E & 0.056 & 0.149 & 0.152 & 0.129 & 0.068 & -0.037 & 0.009 & -0.034 & -0.042 & -0.050 & -0.014 & -0.031 & 0.018 \\
\hline AQ & 0.277 & -0.094 & -0.064 & 0.062 & 1.000 & 0.249 & -0.052 & 0.106 & 0.004 & 0.369 & -0.188 & 0.121 & 0.052 \\
\hline KK & 0.100 & -0.021 & 0.010 & -0.022 & 0.249 & 1.000 & -0.454 & 0.106 & -0.080 & 0.138 & -0.530 & 0.469 & 0.460 \\
\hline REM & -0.046 & -0.076 & -0.094 & -0.086 & -0.052 & -0.454 & 1.000 & -0.182 & 0.015 & -0.045 & 0.255 & -0.400 & -0.234 \\
\hline PC & -0.002 & -0.025 & -0.063 & 0.210 & 0.106 & 0.106 & -0.182 & 1.000 & -0.022 & 0.310 & 0.014 & 0.113 & 0.073 \\
\hline KF*PC & 0.032 & 0.023 & -0.122 & -0.016 & 0.004 & -0.080 & 0.015 & -0.022 & 1.000 & 0.001 & 0.093 & -0.024 & -0.064 \\
\hline SIZE & 0.100 & -0.163 & -0.117 & 0.221 & 0.369 & 0.138 & -0.045 & 0.310 & 0.001 & 1.000 & -0.101 & 0.106 & 0.179 \\
\hline LEV & -0.027 & -0.047 & -0.140 & 0.000 & -0.188 & -0.530 & 0.255 & 0.014 & 0.093 & -0.101 & 1.000 & -0.252 & -0.136 \\
\hline ROA & 0.049 & 0.030 & 0.055 & -0.007 & 0.121 & 0.469 & -0.400 & 0.113 & -0.024 & 0.106 & -0.252 & 1.000 & 0.174 \\
\hline MTBV & 0.048 & 0.018 & 0.060 & 0.030 & 0.052 & 0.460 & -0.234 & 0.073 & -0.064 & 0.179 & -0.136 & 0.174 & 1.000 \\
\hline & & & & & & & & & & & & &
\end{tabular}


The test results show that constructs with adequate discriminatory validity can be caused by the value of the loading of the expected structure being greater than the value of loadings from other structures. Two variables do not meet these criteria, namely audit committee meetings and audit committee expertise where the value is < 0.7. The Fornell-Larcker Criterion is another way to test discriminant validity by comparing each construct of the square root of the AVE greater than the correlation value between constructs in the model.

Table 7. Fornell-Larcker Criterion

\begin{tabular}{|c|c|c|c|c|c|c|c|c|c|c|c|c|c|}
\hline & $\mathrm{KI}$ & $\mathrm{KF}$ & KM & $K V$ & C & $\mathrm{PC}$ & 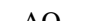 & LFV & & MTDY & $V \mathrm{C}^{*} \mathrm{P} C$ & & \\
\hline KI & 1.000 & & & & & & & & & & & & \\
\hline $\mathrm{KF}$ & -0.431 & 1.000 & & & & & & & & & & & \\
\hline $\mathrm{KM}$ & -0.429 & 0.861 & 1.000 & & & & & & & & & & \\
\hline $\mathrm{KK}$ & 0.100 & 0.010 & -0.021 & 1.000 & & & & & & & & & \\
\hline $\mathrm{AC}$ & -0.230 & -0.023 & -0.017 & -0.022 & 0.699 & & & & & & & & \\
\hline $\mathrm{PC}$ & -0.002 & -0.063 & -0.025 & 0.106 & 0.210 & 1.000 & & & & & & & \\
\hline AQ & 0.277 & -0.064 & -0.094 & 0.249 & 0.062 & 0.106 & 1.000 & & & & & & \\
\hline LEV & -0.027 & -0.140 & -0.047 & -0.530 & 0.000 & 0.014 & -0.188 & 1.000 & & & & & \\
\hline REM & -0.046 & -0.094 & -0.076 & -0.454 & -0.086 & -0.182 & -0.052 & 0.255 & 1.000 & & & & \\
\hline MTBV & 0.048 & 0.060 & 0.018 & 0.460 & 0.030 & 0.073 & 0.052 & -0.136 & -0.234 & 1.000 & & & \\
\hline $\mathrm{KF}^{*} \mathrm{PC}$ & 0.032 & -0.122 & 0.023 & -0.080 & -0.016 & -0.022 & 0.004 & 0.093 & 0.015 & -0.064 & 1.000 & & \\
\hline ROA & 0.049 & 0.055 & 0.030 & 0.469 & -0.007 & 0.113 & 0.121 & -0.252 & -0.400 & 0.174 & -0.024 & 1.000 & \\
\hline SIZE & 0.100 & -0.117 & -0.163 & 0.138 & 0.221 & 0.310 & 0.369 & -0.101 & -0.045 & 0.179 & 0.001 & 0.106 & 1.000 \\
\hline
\end{tabular}

Test Results prove that all constructs have met the criteria. This is because the value of the square root of AVE is greater than the correlation value between constructs. HeterotraitMonotrait Ratio (HTMT) is the third criterion in testing discriminant validity by suggesting that the value should be less than 0.9 which means good and discriminant validity has been achieved.

Table 8. Heterotrait-Monotrait Ratio

\begin{tabular}{|c|c|c|c|c|c|c|c|c|c|c|c|c|c|}
\hline & KI & $\mathrm{KF}$ & KM & KK & $\mathrm{AC}$ & $\mathrm{PC}$ & $\mathrm{AQ}$ & LEV & REM & MTBV & $\mathrm{KF} * \mathrm{PC}$ & ROA & SIZE \\
\hline \multicolumn{14}{|l|}{$\mathrm{KI}$} \\
\hline $\mathrm{KF}$ & 0,431 & & & & & & & & & & & & \\
\hline KM & 0,429 & 0,861 & & & & & & & & & & & \\
\hline KK & 0,100 & 0,010 & 0,021 & & & & & & & & & & \\
\hline $\mathrm{AC}$ & 0,272 & 0,082 & 0,077 & 0,073 & & & & & & & & & \\
\hline $\mathrm{PC}$ & 0,002 & 0,063 & 0,025 & 0,106 & 0,238 & & & & & & & & \\
\hline $\mathrm{AQ}$ & 0,277 & 0,064 & 0,094 & 0,249 & 0,102 & 0,106 & & & & & & & \\
\hline LEV & 0,027 & 0,140 & 0,047 & 0,530 & 0,059 & 0,014 & 0,188 & & & & & & \\
\hline REM & 0,046 & 0,094 & 0,076 & 0,454 & 0,090 & 0,182 & 0,052 & 0,255 & & & & & \\
\hline MTBV & 0,048 & 0,060 & 0,018 & 0,460 & 0,066 & 0,073 & 0,052 & 0,136 & 0,234 & & & & \\
\hline $\mathrm{KF} * \mathrm{PC}$ & 0,032 & 0,122 & 0,023 & 0,080 & 0,071 & 0,022 & 0,004 & 0,093 & 0,015 & 0,064 & & & \\
\hline ROA & 0,049 & 0,055 & 0,030 & 0,469 & 0,045 & 0,113 & 0,121 & 0,252 & 0,400 & 0,174 & 0,024 & & \\
\hline SIZE & 0,100 & 0,117 & 0,163 & 0,138 & 0,242 & 0,310 & 0,369 & 0,101 & 0,045 & 0,179 & 0,001 & 0,106 & \\
\hline
\end{tabular}


THE EFFECT OF GOOD CORPORATE GOVERNANCE AND FINANCIAL DISTRESS ON REAL EARNINGS MANAGEMENT

Santi Yopie and Erika

The test results display the number HTMT $<0.9$ then the model has met the discriminant validity criteria. It is recommended that HTMT $<0.9$ is very good and means that discriminant validity has been achieved.

\section{Reliability}

Composite reliability is an index scale structural, which can be seen in displaying the latent variable coefficients. There are two measuring tools used to evaluate the reliability of composite materials, namely internal consistency / internal consistency and Cronbach's alpha. In the measurement, if the value reaches $>0.6$ then it can be judged that all constructs are reliable and have test credibility / high level of reliability where this situation is because the measurement instrument of each variable has a fairly high correlation.

Table 9. Composite Reliability

\begin{tabular}{ccc}
\hline Variable & Cronbach's Alpha & Composite Reliability \\
\hline KI & 1.000 & 1.000 \\
\hline KM & 1.000 & 1.000 \\
\hline KF & 1.000 & 1.000 \\
\hline AC & 0.638 & 0.757 \\
\hline AQ & 1.000 & 1.000 \\
\hline KK & 1.000 & 1.000 \\
\hline REM & 1.000 & 1.000 \\
\hline KP & 1.000 & 1.000 \\
\hline KF*KP & 1.000 & 1.000 \\
\hline SIZE & 1.000 & 1.000 \\
\hline LEV & 1.000 & 1.000 \\
\hline ROA & 1.000 & 1.000 \\
\hline MTBV & 1.000 & 1.000 \\
\hline
\end{tabular}

From the test results, the composite reliability number for all variables $>0.6$ has met there requirements composite validity. The Cronbach Alpha score on all variables $>0.6$ shows the variables in the model have met the criteria composite reliability.

\section{Inner Model Evaluation}

They are testing the inner model, commonly referred to as the evaluation of the structural model in which there is an influence between latent variables, and assessing the level of model suitability. In a study, the researcher evaluated the internal model analysis through hypothesis testing and model fit consisting of R-square as the dependent construct, Standardized Root Mean Square Residual (SMRM) and GoF Index.

\section{$R$-Square}

R-Square can review the results of the evaluation of the structural model which shows the model if the value is 0.75 it means strong, 0.50 it means moderate, and 0.25 it means weak.

Table 10. R-Square

\begin{tabular}{ccc}
\hline Variable & R-Square & Adjusted R-Square \\
\hline REM & 0.296 & 0.281 \\
\hline
\end{tabular}


The result of the R-Square number test is 0.296. The R-Square Adjusted number gives a value of 0.281 for the REM variable, which means it is weak. The Adjusted R-Square value is 0.281 explaining that the variability of the construct and its interaction is 28.1 which proves that real earnings management can be explained by $28.1 \%$, while the rest explained by other variables outside this study.

\section{Standardized Root Mean Square Residual (SMRM)}

This test is interpreted as the difference between the observed correlation and the inference correlation matrix model. The SMRM value is called the size of the correlation matrix fit in the model. SMRM value $<0.1$ indicates that the model is fit.

Table 11. Standardized Root Mean Square Residual

\begin{tabular}{ccc}
\hline Variable & Saturated Model & Estimated Model \\
\hline SRMR & 0.051 & 0.051
\end{tabular}

The results prove the SRMR value $<0.1$ which indicates that the research model is fit or in accordance with the data. So it can be concluded that the model is suitable.

\section{GoF Index}

The overall model as measured by the root of the average AVE multiplied by the average Adjusted R-Square. If the results obtained from the root are as follows, it can be interpreted according to the value if GoF 0.10 means weak, 0.25 means moderate, and 0.36 means strong. Results GoF valued Index 0509, which means this research model is strong category

Table 12. GoF Index

\begin{tabular}{cccc}
\hline Variable & $\begin{array}{c}\text { Root Average } \\
\text { AVE }\end{array}$ & Root $\mathrm{R}^{2}$ & GoF Index \\
\hline GoF & 0.961 & 0.530 & 0.509 \\
\hline
\end{tabular}

\section{Hypothesis Testing Results}

Path coefficients are outputs that aim to see the direct influence between latent variables. When doing this test, what must be considered is showing the magnitude, direction, and significance of the influence between variables with a T-Statistic value $>1.96$ and a P-Value < 0.05 , which means that it has a significant effect. To see the positive and negative properties, it is taken from the original sample where if it shows $-/+$ then the nature of the relationship is following the original sample.

Table 13. Hypothesis Testing

\begin{tabular}{lccc}
\hline \multicolumn{1}{c}{ Variable } & Original Sample & T Statistics & P Values \\
\hline KI -> REM & -0.107 & 3.107 & 0.002 \\
\hline KM -> REM & -0.009 & 0.144 & 0.886 \\
\hline KF -> REM & -0.113 & 1.855 & 0.064 \\
\hline AC -> REM & -0.113 & 2.235 & 0.026 \\
\hline AQ -> REM & 0.082 & 2.178 & 0.030 \\
\hline KK -> REM & -0.328 & 5.147 & 0.000 \\
\hline KF - PC -> REM & -0.038 & 1.356 & 0.176 \\
\hline
\end{tabular}


THE EFFECT OF GOOD CORPORATE GOVERNANCE AND FINANCIAL DISTRESS ON REAL EARNINGS MANAGEMENT

Santi Yopie and Erika

\section{Hypothesis Testing 1}

The test results show that the relationship between KI and REM is significant with a Tstatistic value of 3.107 which means $>1.96$ and P-Values of 0.002 which means $<0.05$. Original sample shows -0.107 . So the relationship between KI and REM is significantly negative. Then $\mathrm{H}_{1}$ in this research were presented that "Institutional ownership have a significantly negative impact on the real earnings management" acceptable.

The percentage of institutional ownership affects the company's management decision to carry out earnings management, which means that how big or small the institutional ownership affects earnings management actions. It shows that the size of the shares owned by the institution can monitor the company's operations and limit the manager's ability to profit from themselves, so that managers are not relaxed in manipulating the real profits generated by the company. According to research by Setiawati \& Lieany (2016), these results and Susanto \& Pradipta (2016) also showed a significant negative impact on real earnings management.

\section{Hypothesis Testing 2}

From the test results show that the relationship between KM and REM is not significant with a T-statistic of 0.144 which means $<1.96$ and P-Values of 0.886 which means $>0.05$. Original sample shows -0.009 . So the relationship between KM and REM is not significant. Then $\mathrm{H}_{2}$ in this research were presented that "Managerial ownership has a significant positive impact on the real earnings management" is not accepted.

The size of the shares by managers cannot change opportunistic attitudes and behavior in real earnings management practices because managers' shares do not significantly affect institutional shares. Therefore, the institution monitors the manager's opportunistic behavior even though the manager is likely to take earnings management actions. According to research by Kamardin (2014) and Hidayanti \& Paramita (2014), these results show a significant positive impact on real earnings management.

\section{Hypothesis Testing 3}

From the results show the relationship between KF and REM is not significant with a Tstatistic of 1.855 which means $<1.96$ and P-Values of 0.064 which means $>0.05$. Original sample -0.113. So the relationship between KF and REM is not significant. Then $\mathrm{H}_{3}$ in this research were presented that "Family ownership have significantly negative impact on the real earnings management" is not accepted. This situation proves that family share ownership cannot monitor and reduce the actions of managers in real earnings management practices. So family ownership cannot control the opportunistic actions of managers in creating profits for personal purposes that sometimes do not benefit the company. These results are not in line with Yulaeli (2018) and Ghaleb et al. that shows a significant negative impact on real earnings management, which means that family ownership can control company management.

\section{Hypothesis Testing 4}

The test results show that the relationship between KA and REM is significant with a Tstatistic of 2.235 which means $>1.96$ and P-Values of 0.026 which means $<0.05$. Original sample -0.113. So the relationship between KA and REM is significantly negative. Then $\mathrm{H}_{4}$ in this research were presented that "Audit committee has a significantly negative impact on the real earnings management" acceptable.

The company has sufficient resources to supervise or monitor the company's operational activities if it has a large audit committee size because the audit committee functions as a supervisor related to the resources she/he has. To not harm minority shareholders, an independent audit committee is needed to ensure that financial decisions are made in the best 
interests of all shareholders. Audit committee can increase supervision on preparation of financial statements prepared by managers. So that managers feel inhibited in their freedom to manipulate financial statements so that earnings management actions are suppressed. According to research by Haji-Abdullah \& Wan-Hussin (2015) and Wicaksono et al. (2016), these results also showed a significant negative on real earnings management.

\section{Hypothesis Testing 5}

The results show the relationship between AQ and REM is significant with a T-statistic of 2.178 which means $>1.96$ and P-Values of 0.030 which means $<0.05$. Original sample 0.082 . So the relationship between AQ and REM is significantly positive. Then $\mathrm{H}_{5}$ in this research were presented that "Audit quality has a significant positive impact on the real earnings management" acceptable. A better quality auditor can reduce accrual earnings management and switch to real earnings management when the company has a strong urge to require earnings management. According to research by Boedhi \& Ratnaningsih (2017) and Lestari \& Aeni (2019), these results showed that there is a significant positive impact on real earnings management.

\section{Hypothesis Testing 6}

The test results show the relationship between KK and REM is significant with a Tstatistic of 5,147 which means > 1.96 and P-Values of 0.000 which means <0.05. Original sample -0.328 . So the relationship between KK and REM is significantly negative. Then $\mathrm{H}_{6}$ in this research was presented that "Financial distress has a significant negative impact on the real earnings management" acceptable. The higher the distress experienced by the company will increase the real earnings management carried out by management to influence investors that the company is in a safe position to avoid distress. The higher the distress of a company will not affect the company's management. Management takes these actions to attract investors and maintain the company's name in the eyes of investors and the public. These results according to research by Muljono \& Suk (2018), Yulaeli (2018), and Feldo, Rinaningsih, \& Yuliati (2019) also showed that there is a significant negative impact on real earnings management.

\section{Hypothesis Testing 7}

The test results show that the relationship between KF and REM moderated by PC is not significant with a T-statistic of 1.356 which means $<1.96$ and P-Values of 0.176 which means $>0.05$. Number of original sample -0.038. So the relationship between KF and REM moderated by $\mathrm{PC}$ is not significant. Then $\mathrm{H}_{7}$ in this research were presented that "Family ownership have significant positive impact on the real earnings management moderated by political connection" is not accepted. There is no proven political connection because the company is indicated to have political relations, does not have legal leniency if it is proven to carry out earnings management. These result are not fit with research by Braam et al., (2015) and Apriyani et al., (2019) that shows a significant positive impact on real earnings management.

\section{CONCLUSIONS AND SUGGESTIONS}

This study is used to analyze the effect of good corporate governance and financial distress on real earnings management moderated by political connections. Based on the results of the analysis above, it can be concluded that institutional ownership has a significant negative impact on real earnings management, managerial ownership has no significant impact on real earnings management, family ownership has no significant impact on real earnings 
management, audit committee has a significant negative impact on real earnings management, audit quality has a significant positive impact on real earnings management, financial distress have a significant negative impact on real earnings management, and family ownership has no significant impact on real earnings management which is moderated by political connections.

This study still has shortcomings and limitations to be used as a consideration for future research in order to get result a better for future research. The limitations in this study are the research sample is a manufacturing company listed on the IDX, there are 49 companies listed on the IDX whose IPO after 2015, there is 1 company that is not listed on the IDX, and there are 8 companies whose data are incomplete.

There are suggestions for researchers to give to previous researchers, which adding a moderating variable for each existing independent variable in order to give more influence on the dependent variable in order to produce a good test, expand in the selection of research objects and using a suitable measurement method for each variable. Companies should pay more attention to the factors that influence real earnings management actions considering that real earnings management is more favored by managers than accruals because real earnings management has a direct influence on current and future cash flows, making it more difficult to detect than accruals. If the company is not careful about real earnings management actions, it will have a negative impact on operating performance in the future which has the potential to reduce the value of the company. Investors should be more careful in making investment decisions, and pay attention to factors that affect the company's management actions that benefit themselves, but reduce the value of the company in the future. This is necessary so that investors can make the right decisions in investing.

\section{REFERENCES}

Adiguzel, H. (2013). Corporate Governance, Family Ownership and Earnings Management: Emerging Market Evidence. Accounting and Finance Research, 2(4), 17-33. https://doi.org/10.5430/afr.v2n4p17

Apriyani, Ika, S. R., \& Sarnowo, H. (2019). Pengaruh Koneksi Politik Dan Corporate Governance Terhadap Manajemen Laba. ISEI Economic, 2(1), 8-15. https://doi.org/https://doi.org/10.36217/ier.v3i1.76

Boedhi, N. R., \& Ratnaningsih, D. (2017). Pengaruh Kualitas Audit Terhadap Manajemen Laba Melalui Aktivitas Riil. Kinerja, 19(1), 84. https://doi.org/10.24002/kinerja.v19i1.536

Braam, G., Nandy, D. M., Weitzel, U., \& Lodh, S. (2015). Accrual-based, Real Earnings Management and Political Connections. International Journal of Accounting, 50(2), 111141. https://doi.org/10.1016/j.intacc.2013.10.009

Chandra, B. (2021). Pengaruh koneksi politik, kinerja perusahaan dan karateristik perusahaan terhadap manajemen laba di indonesia The effect of political connection, firm performance and firm characteristic on earning management in Indonesia. Inovasi, 17(1), 35-45. https://doi.org/http://dx.doi.org/10.29264/jinv.v17i1.9167

Dwiyanti, K. T., \& Astriena, M. (2018). Pengaruh Kepemilikan Keluarga Dan Karakteristik Komite Audit Terhadap Manajemen Laba. Jurnal Riset Akuntansi Dan Bisnis Airlangga, 
3(2), 447-469. https://doi.org/10.31093/jraba.v3i2.123

Farouk, M. A., \& Bashir, N. M. (2017). Ownership structure and earnings management of listed conglomerates in Nigeria. Journal of Accounting and Finance, 1(4), 42-54. https://doi.org/https://doi.org/10.52962/ipjaf.2017.1.4.27

Feldo, F., Rinaningsih, R., \& Yuliati, R. (2019). Hubungan Kesulitan Keuangan Dengan Manajemen Laba Pada Perusahaan Yang Terdaftar Di Bursa Efek Indonesia Tahun 20102016. Jurnal Ekonomi Manajemen Akuntansi, 21(2), 141. https://doi.org/10.34209/equ.v21i2.640

Ghaleb, B. A. A., Kamardin, H., \& Tabash, M. I. (2020). Family ownership concentration and real earnings management: Empirical evidence from an emerging market. Cogent Economics and Finance, 8(1). https://doi.org/10.1080/23322039.2020.1751488

Haji-Abdullah, N. M., \& Wan-Hussin, W. N. (2015). Related party transactions, audit committees and real earnings management: The moderating impact of family ownership. Advanced Science Letters, 21(6), 2033-2037. https://doi.org/10.1166/asl.2015.6195

Hidayanti, E., \& Paramita, R. W. D. (2014). Pengaruh Good Corporate Governance Terhadap Praktik Manajemen Laba Riil Pada Perusahaan Manufaktur. Jurnal WIGA, 4(2), 1-15. https://doi.org/https://doi.org/10.30741/wiga.v4i2.120

Kamardin, H. (2014). Managerial Ownership and Firm Performance: The Influence of Family Directors and Non-family Directors. 47-83. https://doi.org/10.1108/s2043052320140000006002

Kharashgah, K. A., Amran, N. A. B., \& Ishak, R. B. (2019). The Impact of Audit Committee Characteristics on Real Earnings Management: Evidence from Jordan. International Journal of Academic Research in Accounting, Finance and Management Sciences, 9(4), 84-97. https://doi.org/10.6007/ijarafms/v9-i4/6699

Khuong, N. V., Ha, N. T. T., \& Thu, P. A. (2019). The relationship between real earnings management and firm performance: the case of energy firms in Vietnam. International Journal of Energy Economics and Policy, 9(2), 307-314. https://doi.org/10.32479/ijeep.7469

Lestari, N., \& Aeni, N. (2019). The Effect Of Audit Quality And Earnings Management On Firm Performance. 377(Icaess), 36-41. https://doi.org/10.2991/icaess-19.2019.7

Mahadi, T. (2021). Manipulasi laporan keuangan, dua eks bos Tiga Pilar (AISA) divonis 4 tahun penjara. Kontan. https://nasional.kontan.co.id/news/manipulasi-laporan-keuangandua-eks-bos-tiga-pilar-aisa-divonis-4-tahun-penjara

Melinda, \& Widyasari. (2019). Faktor Yang Mempengaruhi Manajemen Laba Perusahaan Manufaktur Yang Terdaftar di BEI. Jurnal Multiparadigma Akuntansi, 1(2), 452-359. https://doi.org/http://dx.doi.org/10.24912/jpa.v1i2.5014

Muljono, D. R., \& Suk, K. S. (2018). Impacts of financial distress on real and accrual earnings management. Jurnal Akuntansi, 22(2), 222. https://doi.org/10.24912/ja.v22i2.349 
THE EFFECT OF GOOD CORPORATE GOVERNANCE AND FINANCIAL DISTRESS ON REAL EARNINGS MANAGEMENT

Santi Yopie and Erika

Ningsih, S. (2015). Earning Management melalui Aktivitas Rill dan Akrual. Jurnal Akuntansi Dan Pajak, 16(1), 55-66. https://doi.org/http://dx.doi.org/10.29040/jap.v16i01.22

Santoso, Y. I. (2021). PMI Manufaktur dan Inflasi Agustus membaik, ini kata pemerintah. Kontan. https://newssetup.kontan.co.id/news/pmi-manufaktur-dan-inflasi-agustusmembaik-ini-kata-pemerintah?page=all

Setiawati, L. W., \& Lieany. (2016). Analisis Pengaruh Perjanjian Utang, Kepemilikan Institusional, Dan Ukuran Perusahaan Terhadap Manajemen Laba Riil Pada Perusahaan Manufaktur Yang Terdaftar Di Bursa Efek Indonesia. Jurnal Akuntansi, 9(2), 172-197. https://doi.org/10.25170/jara.v9i2.34

Susanto, Y. K., \& Pradipta, A. (2016). Corporate Governance and Real Earnings Management. International Journal of Business, Economics and Law, 9(1), 17-23. https://doi.org/http://dx.doi.org/10.35609/jfbr.2020.5.2(2)

Wareza, M. (2019). Tiga Pilar dan Drama Penggelembungan Dana. CNBC Indonesia. https://www.cnbcindonesia.com/market/20190329075353-17-63576/tiga-pilar-dandrama-penggelembungan-dana

Wicaksono, T., Pambudi, A., \& Miftah, D. (2016). Analisis Pengaruh Komposisi Dewan Komisaris, Karakteristik Komite Audit, dan Struktur Kepemilikan Manajerial Terhadap Praktik Real Earnings Management. Jurnal Al-Iqtishad, I(June), 55-70. https://doi.org/http://dx.doi.org/10.24014/jiq.v12i1.4445

Yulaeli, T. (2018). Pengaruh Cost of REM Terhadap Real Earnings Management dengan Aset dan Market to Book Value sebagai Variabel Kontrol. Jurnal Buana Akuntansi, 3, 73-94. https://doi.org/https://doi.org/10.36805/akuntansi.v3i1.229 